\title{
Task and Function of Apparatus at Sei Balai Sub-District Office, Batubara Regency, Indonesia
}

\author{
Supiah Ningsih \\ Lecturer in Muhammadiyah Economic Education Higher Education, Asahan (STIEMA), Indonesia \\ email: supiah.ningsih@yahoo.co.id
}

\begin{abstract}
Coal has good skills and attitudes in work, such as being able to work well with co-workers, so that it can improve its work effectiveness which will provide a great opportunity for employees to move forward and improve their position in the organization. Sei District Head Office District districts. The place of research was carried out at the Sei Sub-District Head Office, Kab. Coal located at Jalan Lintas Sumatra, Durian District, Kab. Coal. Research Time starts from May 2017 to July 2017. The population in this study were all employees at the Sei Sub-District Head Office, Kab. Coal, amounting to 30 people. Employees at Sei Sub-District Head Office District. Coal has good skills and attitudes in work, such as being able to work well with co-workers, so that it can improve its work effectiveness which will provide a great opportunity for employees to move forward and improve their position in the organization. Sei District Head Office District districts.
\end{abstract}

Keyword: Coal; Aparatus; Batubara Regency

\section{Introduction}

With increasingly sharp competition due to rapid technological changes and a dynamic environment in every aspect of human life, every organization needs human resources who have the competence to be able to provide excellent and valuable services. Environmental changes are so fast demanding their ability to capture the phenomenon of change, analyze its impact on the organization and prepare steps to deal with these conditions. The success of the organization is largely determined by the quality of the people who work in it. The low quality of human resources in the organization causes a decrease in the effectiveness of employee work, which is indirectly determined by competence (Wibowo, 2007: 87).

According to Hasibuan (2003: 105) Work effectiveness is a condition that shows the level of success of management activities in achieving goals. The success rate includes the quantity of work, good quality of work, and the timeliness of completing work. To achieve work effectiveness it needs to be supported by human resources who have the competencies needed by the company so as to obtain effective and efficient results. According to Hutapea and Thoha (2008: 5) one of the factors that support increased work effectiveness is competence. Competence is a basic characteristic of a person consisting of knowledge, skills, and attitudes that have a causal relationship with outstanding work performance or work effectiveness. Effectiveness which is interpreted as the success of conducting a program is influenced by various factors that can determine whether the effectiveness of the employee's work is successful or not. According to Moeheriono (2009: 4) competence is a basic characteristic of someone who indicates how to think, behave and act and draw conclusions that can be done and maintained by a person at a certain period of time. 
Having competent human resources is a must for a company. Managing HR based on competency is believed to be able to guarantee the success of achieving goals. Most companies use competency as a basis for selecting people, managing performance, training and developing and providing compensation. Competency analysis is composed mostly for career development, but determining the level of competence is needed to determine the effectiveness of the expected level of performance. Award is one form of recognition given to employees who have shown extraordinary loyalty and achievement. According to Sastrohadiwiryo (2002: 269), appreciation for a performance achieved will be a strong incentive. Recognition of a performance will provide higher inner satisfaction than awards in the form of material or prizes, awards in the form of awards or medals, can make stimulants which is stronger than the gift of goods or bonuses / money.

\section{Review of Literature}

\subsection{Definition of Work Effectiveness}

Work effectiveness is a condition of achieving the expected or desired goals through the completion of the work in accordance with the predetermined plan. The understanding of effectiveness according to experts includes the following. according to Siagian (2007: 24) effectiveness is the use of resources, facilities and infrastructure in a certain amount that is consciously set beforehand to produce a number of goods for services carried out. Effectiveness shows success in terms of whether or not the target has been achieved. If the results of the activity get closer to the target, the higher the effectiveness. When observed that the effectiveness of work in an organization both private and government, the target is focused on the implementation process and the level of success of the activities carried out by the employees themselves. the activity in question is a business that can provide maximum benefit for the organization. The terms effective (effective) and (efficien) are interrelated terms that deserve to be lived in an effort to achieve the goals of an organization. In principle, the individual effectiveness of its members in carrying out tasks in accordance with their respective positions and roles in the organization. Work effectiveness is often defined as an achievable goal. Efficient is the rate at which operations are carried out economically (Mathis and Jackson, 2001: 104). To be effective, companies must be able to achieve goals, but in the most efficient way in the use of human resources. Work effectiveness is a condition that shows the results of human effort in achieving the desired goals in accordance with what they want (Daft, 2001: 85).

According to Hutapea and Thoha (2008: 59), effectiveness in organizations can be evaluated by looking at two things, namely:

1) Achieving goals.

2) The process of implementing the organization, which is reflected in organizational behavior when interacting with the internal and external environment.

Both the achievement of the target and the organization's implementation process have the same important role for the organization because the achievement of goals that are not accompanied by a good organizational implementation process will result in long-term achievement of the target. In other words, a bad organizational process will be able to reduce the level of efficiency that results in a decrease in the achievement of targets in the next period. Effectiveness which is interpreted as the success of conducting a program is 
influenced by various factors that can determine whether the effectiveness of the employee's work is successful or not.

\subsection{Factors Affecting Work Effectiveness}

Factors that influence work effectiveness in the organization, among others:

1) Time

Timeliness in completing a job is a major factor. The longer the task charged is done, the more other tasks that follow. This will reduce the level of work effectiveness because it takes a lot of time.

2) Tasks

Employees must be informed of the purpose and importance of the tasks delegated to them.

3) Productivity

An employee has high work productivity in work, of course it can produce good work effectiveness, and vice versa.

The use of effective and directed labor is the key to increasing effectiveness so that a company policy is needed to move the workforce to work more productively in accordance with the plans set by the company. To function effectively, who should be served. According to Hasibuan (2007: 94) productivity is a comparison between the outputs (outputs) achieved with input (input) given. So, the effectiveness of labor contains an understanding of the comparison between the results achieved with the participation of labor per unit of time.

Improving the quality of human resources is certainly very necessary to realize the results expected by each company. Every employee in the company should be directed to further increase the effectiveness of their work through various stages of business to the fullest. Efforts to improve work effectiveness can be done by training and developing and coaching employees, and most importantly is supported by competent human resources who have knowledge, skills and attitude. So that with the utilization of competent human resources will be more supportive of the success of the company.

\section{Methodology}

The place of research was carried out at the Sei Sub-District Head Office, Kab. Coal located at Jalan Lintas Sumatra, Durian District, Kab. Coal. Research Time starts from May 2017 to July 2017. According to Sugiyono (2006: 72), the population is an area of generalization consisting of objects / subjects that have certain qualities and characteristics set by researchers to be studied and then drawn conclusions. Thus, the population in this study were all employees at the Sei Sub-District Head Office, Kab. Coal, amounting to 30 people. The sample is part of the number and characteristics possessed by the population. Then the sample in this study uses Saturated Sampling method. According to Sugiyono (2006: 78), saturated sampling is a sampling technique when all members of the population are used as a sample, which is 30 people. Another term saturated sample is a census, because the population is relatively small and tends to be heterogeneous.

\section{Discussion}

\section{Camat}


Task details are as follows:

i. Formulate District Government policy formulation which includes government affairs, Village and Village empowerment, community economic development and social welfare of the community and carry out the tasks of the Regional government delegated to the Subdistrict, carrying out co-administration tasks assigned by the Regional Government, fostering and coordinating the implementation of the duties of the Technical Implementation Unit Services in the District;

ii. Arrange and distribute tasks to the Secretary to be submitted to the Sections of the District Government;

iii. Provide guidance and direction to the District Secretary and the Section Heads so that the implementation of the tasks is in accordance with the applicable instructions and provisions;

iv. Coordinate the District Secretary and the Section Heads directly or through periodic meetings to establish a good cooperative relationship and mutual support in carrying out their respective duties;

v. Monitor and evaluate the implementation of tasks within the District Secretariat and Section to find out developments, obstacles and problems that arise and efforts to follow-up the settlement;

vi. Researching, disposing, initialing and signing correspondence relating to the District Government;

vii. Solving problems that arise in the implementation of tasks in the District Government;

viii. Submit suggestions and considerations to the Regent / Deputy Regent and Regional Secretary regarding the District Government;

ix. Coordinate the implementation of administrative coaching and provide administrative technical services to sub-district government organizational units which include planning, legal and information matters, general affairs, financial management and monitoring and evaluation;

x. Coordinate the implementation of general government affairs, fostering public services, fostering peace and order and fostering efforts to increase regional income;

xi. Coordinate the implementation of coaching in the framework of empowering village / kelurahan government, government and village / village community institutions as well as fostering village / kelurahan resource development;

xii. Coordinate the implementation of community economic business development which includes the development of village / kelurahan potential, cleanliness, beauty, physical and infrastructure as well as economic development, production, distribution and marketing;

xiii. Coordinate with related agencies and carry out community, mental and spiritual wellbeing and social problem management;

xiv. Fostering and implementing cooperation in the field of sub-district government with government agencies and other parties in accordance with the applicable laws and regulations and government policies;

xv. Assessing the work of subordinates in the District Government environment based on the results achieved as material for employee career improvement;

xvi. Report the results of the implementation of the tasks of the District Government to the Regent through the Regional Secretary as a responsibility and assessment of superiors; 
xvii. Carry out part of the Regent's authority which is submitted to the Camat in carrying out government affairs which are the authority of the Regency;

xviii. Carry out other tasks given by the Regent / Deputy Regent and Regional Secretary in accordance with the field of duties and problems.

2. District Secretary

Task details are as follows:

i. Coordinate the preparation of the activities of the District Secretariat based on the main tasks and functions as well as the Vision and Direction of Regional Development as well as previous activities in carrying out the tasks;

ii. Implementation and management of general administration and household and equipment;

iii. Management of personnel administration, development of administration, finance and organizational development and management;

iv. Implementation of treasurer and PPTK coaching in the Subdistrict environment;

v. Regulate and distribute tasks to Section Heads within the District Secretariat in accordance with applicable regulations and provide direction in accordance with their duties and problems;

vi. Coordinate the Section Heads in the District Secretariat both directly and through periodic meetings to establish a good cooperative relationship and mutual support in the implementation of their respective duties;

vii. Distribute letters according to the disposition of the Camat, both outside and in the District Government;

viii. Coordinate the implementation of the tasks of developing development plans and programs as well as the administration of financial administration which includes budgeting, administration and preparing financial accountability:

ix. Coordinate the implementation of the task of compiling and preparing materials for the implementation of legal guidance, dissemination of information on the results of development to the community;

x. Coordinate the implementation of the tasks of administrative affairs, filing, household and equipment as well as the administration and welfare of employees;

xi. Carry out monitoring and control of the results of the implementation of activities in the sub-district area;

xii. Organizing organizational guidance and governance in the District Government;

xiii. Coordinate the preparation of reports on the implementation of tasks of the District government;

xiv. Assessing the work performance of subordinates within the Secretariat based on the results achieved as material for improving employee career;

xv. Submit suggestions and considerations to superiors concerning the field of administrative services in organizational units in the District Government;

xvi. Make reports on the implementation of the activities of the District Secretariat to superiors as accountability and assessment of superiors;

xvii. Carry out other tasks given by the supervisor in accordance with the field of tasks and problems.

3. General and Personnel Subdivision 
Details of this task are:

i. Preparation of operational work plans and programs for the activities of general administration services, housekeeping and equipment as well as management of personnel administration;

ii. Carry out correspondence affairs both in and out letters;

iii. Carry out the agenda of correspondence, filing, and expedition;

iv. Carry out the management and administration of households, goods and equipment;

v. Carry out the management and administration of personnel and the development of human resources;

vi. Carry out monitoring, controlling, monitoring and evaluating the activities of managing correspondence, filing and documentation of legal and activity products, household and personnel management;

vii. Implementation of management and preparation of guidance and documentation materials;

viii. Implementation of management and control of official travel administration;

ix. Implementation of protocol services, public relations and organizing meetings;

$\mathrm{x}$. Implementation of housekeeping, maintenance of cleanliness of office buildings, maintenance of official vehicles and other assets as well as security and order of the District Scope;

xi. Preparation and preparation of plans for the needs of the District Office equipment and infrastructure;

xii. The implementation of storage, distribution and inventory of procurement office equipment;

xiii. Implementation of personnel administration management which includes promotion, periodic salary, retirement, KARPEG, KARIS / KARSU, TASPEN, ASKES, employee leave, awarding and coordinating the preparation of SKP;

xiv. Coordinate the preparation of Standard Operating Procedures, Position Analysis and Analysis of District Environmental Workloads;

xv. Implementation of the collection, storage and maintenance of personnel documentation data;

xvi. Compile reports on the activities of managing correspondence, filing and documentation of legal and activity products, households and personnel management;

xvii. Carry out other tasks given by the boss in accordance with each.

4. Finance Subdivision and Program

Details of this task are:

i. $\quad$ Prepare plans and programs, evaluation and reporting;

ii. Prepare a Work Plan and Budget (RKA) and Budget Implementation Documents (DPA) determination and change;

iii. Coordinating and drafting of RENSTRA, RENJA, Performance Agreements, Performance Reports, LPPD and LKPJ;

iv. Coordinate the financial management administration of the work unit starting from the making of the Payment Request Letter (SPP) up to the collection of evidence of financial accountability as well as the General Cash Book and Financial Assistance Book; 
v. Prepare evaluation material and report on the development of the absorption of the activity budget;

vi. Compile financial and accounting reports;

vii. Carry out general and technical policies in the financial sector;

viii. Carry out, verify, treasury and bookkeeping;

ix. Manage the income and expenditure budget;

$\mathrm{x}$. Coordinate the preparation of accountability reports for the implementation of activities;

xi. Carry out analysis and evaluation of the implementation of activities;

xii. Submit suggestions and considerations to superiors for smooth implementation of activities;

xiii. Carry out other official duties in accordance with the applicable laws and regulations.

\section{Governance Section}

Task details are as follows:

i. Formulate an action plan for the Governance Section based on the main tasks and functions as well as data and work programs of the District Government and the applicable provisions as a work guideline;

ii. Dividing assignments to subordinates in accordance with applicable rules and regulations and giving directions according to the field of tasks and problems:

iii. Supervising and evaluating staff activities within the Governance Section to find out problems so that no irregularities occur;

iv. Prepare and compile materials for implementing governance affairs;

v. Carry out village and village administration administration coaching;

vi. Preparing materials and implementing public services;

vii. Conduct guidance and efforts to resolve land disputes and administer land registration;

viii. Coordinate and collaborate with relevant agencies at the District level;

ix. Ostering activities of socio-political and community organizations, ideology of the State and national unity as well as assisting in the implementation of elections;

$\mathrm{x}$. Inventory of problems related to the Governance Section and prepare the solutions;

xi. Assessing the work performance of subordinates in the Governance Section based on the results achieved as material for employee career improvement;

xii. Submit suggestions and considerations to superiors regarding the implementation of the duties of the Governance Section for guidance and further improvement of tasks;

xiii. Make a population report and implementation of the Governance Section;

xiv. Carry out other tasks given by the supervisor in accordance with the field of tasks and problems.

6. Community and Village Empowerment Section

Task details are:

i. Prepare a plan for the activities of the Community and Village Empowerment Section based on the main tasks and functions as well as data and work programs of the District Government and the applicable provisions as a work guideline;

ii. Dividing assignments to subordinates in accordance with the applicable rules and regulations and giving directions according to the field of tasks and problems; 
iii. Coordinate subordinates in the Community and Village Empowerment Section environment both directly and through periodic meetings to establish good cooperative relationships and mutual support in the implementation of their respective tasks;

iv. Coordinate the implementation of the duties of coaching and administrative services of the administration of the Village government in accordance with the provisions and policies established by the Region;

v. Coordinate the implementation of coaching tasks in order to empower village government institutions and social institutions;

vi. Coordinate the implementation of coaching tasks in the framework of developing natural resources and human resources as well as carrying out guidance on the excavation, development and management of village / kelurahan income and financial sources;

vii. Organize and distribute tasks to subordinates in the Community and Village Empowerment Section both in writing and verbally in accordance with their fields and problems;

viii. Researching and selecting the concept plan for section activities in the Community and Village Empowerment Section so that it is in accordance with the applicable plans and provisions;

ix. Monitor and evaluate the implementation of section activities in the Community and Village Empowerment Section environment to find out developments, obstacles and problems that arise as well as follow-up efforts to resolve them;

x. Coordinate the implementation of ADD, DD and variables with the Village and Village assistants;

xi. Assessing the work performance of subordinates in the Community and Village Empowerment Section environment based on the results achieved as material for employee career improvement;

xii. Submit suggestions and considerations to superiors regarding Community and Village Empowerment Section for guidance and further improvement of tasks;

xiii. Submit a report on the implementation of Community and Village Empowerment Section activities to superiors as accountability and assessment of superiors;

xiv. Carry out other tasks given by the supervisor in accordance with the field of tasks and problems.

7. Peace and Public Order Section

Task details are:

i. Compile a plan for the activities of the Peace and Public Order Section by referring to the main tasks and functions as well as data and work programs of the District Government and the applicable provisions as work guidelines;

ii. Dividing assignments to subordinates in accordance with the applicable rules and regulations and giving directions according to the field of tasks and problems;

iii. Supervising and evaluating staff activities within the Peace and Public Order Section to find out problems so that no irregularities occur;

iv. Preparing materials in the framework of drafting the concept of policies, guidelines and technical guidelines for the Peace and Public Order Section;

v. Organizing peace and public order coaching; 
vi. Preparing materials for developing national insight and community protection and fostering community organizations;

vii. Inventory of problems related to the Public Order and Peace Section and prepare the solutions;

viii. Preparing materials in the framework of drafting the concept of policies, guidelines and technical instructions for controlling general licensing;

ix. Carry out the issuance of licensing that is delegated to the District in accordance with applicable regulations;

$\mathrm{x}$. Conducting public order development, including orderly licensing;

xi. Assessing the work performance of subordinates within the Peace and Public Order Section based on the results achieved as material for employee career improvement;

xii. Submit suggestions and considerations to superiors regarding the implementation of the tasks of the Peace and Public Order Section for guidance and further enhancement of duties;

xiii. Make reports on the implementation of the Peace and Public Order Section activities to superiors as accountability and assessment of superiors;

xiv. Carry out other tasks given by the supervisor in accordance with the field of tasks and problems.

8. Education and Social Culture Section

Task details are:

i. Compile an activity plan for the Education and Socio-cultural Section based on the main tasks and functions as well as data and work programs of the District Government and the applicable provisions as work guidelines;

ii. Dividing assignments to subordinates in accordance with the applicable rules and regulations and giving directions according to the field of tasks and problems;

iii. Give instructions and guidance to subordinates in the Education and Socio-Cultural Section environment in accordance with the applicable instructions and provisions;

iv. Coordinate subordinates within the Education and Socio-Cultural Section environment both directly and through periodic meetings to establish a good cooperative relationship and mutual support in the implementation of their respective tasks;

v. Coordinate the implementation of the task of coordinating and implementing social assistance programs, social, literature, youth, women's roles and sports;

vi. Coordinate the implementation of the task of coordinating and implementing mental and spiritual development programs which include fostering religious life, education and public health;

vii. Coordinate the implementation of the task of coordinating and implementing programs for the development and overcoming of social problems which include community disease prevention, disaster victims and drug victims;

viii. Inventory of problems related to the Education and Socio-Cultural Section and prepare the solutions;

ix. Assessing the work performance of subordinates in the Education and Socio-Cultural Section environment based on the results achieved as an employee career improvement material;

x. Submit suggestions and considerations to superiors regarding the Education and Socio-Cultural Section for guidance and further improvement of tasks; 
xi. Submit reports on the implementation of the activities of the Education and SocioCultural Section to superiors as accountability and assessment of superiors;

xii. Carry out other tasks given by the supervisor in accordance with the field of tasks and problems.

9. Community Service Section

Task details are:

i. Compile an activity plan for the Community Service Section based on the main tasks and functions as well as data and work programs of the District Government from the applicable provisions as work guidelines;

ii. Conduct guidance and efforts to increase District income;

iii. Carry out coaching and citing regional revenue;

iv. Dividing assignments to subordinates in accordance with the applicable rules and regulations and giving directions according to the field of tasks and problems;

v. Provide guidance and guidance to the Staff in the Community Service Section in accordance with the applicable instructions and provisions;

vi. Coordinate Employees in the Community Service Section both directly and through periodic meetings to establish good cooperative relationships and support each other in carrying out their respective tasks;

vii. Coordinate the implementation of the task of fostering excavation, development and management of the potential of the Village;

viii. Coordinate the implementation of the task of guidance on the cleanliness and beauty of the Environment;

ix. Coordinate the implementation of the task of guidance and utilization of physical development and infrastructure so that it can be efficient and effective;

x. Coordinate the implementation of the task of fostering economic improvement, production and improving the smooth distribution and marketing of community products;

xi. Examine and select the concept of the plan for the activities of the Community Service Section in accordance with the applicable plans and provisions;

xii. Monitor and evaluate the implementation of sub-section activities in the Community Service Section to find out developments, obstacles and problems that arise as well as follow-up efforts to resolve them;

xiii. Assess the work performance of subordinates in the Community Service Section based on the results achieved as material for improving employee career;

xiv. Carry out other tasks given by the supervisor in accordance with the field of tasks and problems.

\section{Conclusion}

Employees at Sei Sub-District Head Office District. Coal has good skills and attitudes in work, such as being able to work well with co-workers, so that it can improve its work effectiveness which will provide a great opportunity for employees to move forward and improve their position in the organization. Sei District Head Office District districts. Coal is 
more supervising and monitoring the work effectiveness of its employees, which can be seen through the skills possessed by employees, namely by giving assignments and workloads, where it encourages a greater sense of responsibility to the employees. Coal should provide opportunities / great opportunities for employees to be able to complete the work that is charged by the agency in a team or group collaboration. Office of the Head of District Sei Balai districts. Coal is expected to conduct more coaching, training, and development for competency enhancement that must be owned by employees, which includes skills, knowledge, and attitude so that the work effectiveness of employees can be more realized in carrying out each task and workload given by the agency more ready and more efficient to achieve company goals that are based on standard operating procedures established by the Sei District Head Office District districts. Coal.

\section{References}

Danim, Stephen P. 2004. Prinsip-prinsip Perilaku Organisasi, Penerbit Erlangga,Jakarta. Daft, Richard L. 2003. Manajemen Sumber Daya Manusia, Penerbit Erlangga, Jakarta. Ghani. 2003. Manajemen, PT. Raja Grafindo Persada, Jakarta.

Graham, Tanjung. 2003. Pengantar Statistika, Edisi Ketiga, Penerbit PT Gramedia Pustaka Utama, Jakarta.

Hasibuan, Malayu SP. 2007. Manajemen Sumber Daya Manusia, Edisi Revisi, Bumi Aksara, Jakarta.

Hutapea, Parulian dan Nurianna Thoha. 2008. Kompetensi Plus, PT.Gramedia PustakaUtama, Jakarta.

Kreitner dan Kinicki. 2005. Performance Management, Edisi Bahasa Indonesia, Sun, Jakarta.

Mankunegaran. 2006. Manajemen Sumber Daya Manusia, BumiAksara, Jakarta.

Mathis, Robert L, Jackson, John H. 2002. Manajemen Sumber Daya Manusia, Jilid Kedua, Penerbit Salemba Empat, Jakarta.

Moeheriono. 2009. Pengukuran Kinerja Berbasis Kompetensi, Penerbit Ghalia Indonesia.

Mahsun, Achmad. 2006. Sistem Manajemen Kinerja, PT. Gramedia, Jakarta.

Nawawi, Dermawan. 2003. Manajemen Kinerja, Penerbit Erlangga, Jakarta.

Sastrohadiwiryo. 2002. Azas-azas Penelitian behavioral, Gadjah Mada UniversityPress, Yogyakarta.

Siagian, P. Sondang. 2007. Manajemen Sumber Daya Manusia,PenerbitSalemba Empat, Jakarta.

Wibowo. 2007. Manajemen Kinerja, PT. Raja Grafindo Persada, Jakarta. 